УДК 811. 111'373. 611

DOI: 10.37026/2520-6427-2020-103-3-114-117
Ірина ОНИЩЕНКО,

стариий викладач кафедри іноземних мов природничо-математичних спеціальностей Східноєвропейського національного університету імені Лесі Українки, м. Луиьк

Анжеліка ЯНОВЕЦЬ,

кандидат філологічних наук,

доиент кафедри української та іноземної лінгвістики

Луиьького національного технічного університету

\title{
КОМПОЗИТИ В СУЧАСНІЙ АНГЛІЙСЬКІЙ МОВІ ЯК СКЛАДОВА СЕМАНТИЧНӦ̈ КОНДЕНСАЦІЇ ЛЕКСИКИ
}

\begin{abstract}
У статті окреслено роль композитології-науки про складне слово, щзо розвивається на фоні автономізаиії словотворення й обумовлена становленням словотворення як самостійної галузі лінгвістичних досліджень. Доведено, щзо виникнення композитів ие не специфічний прочес, обумовлений широким розповсюдженням в сучасній англійській мові словоскладання, а передусім один із проявів загального процесу семантичної конденсаиї лексики, що відбувається в багатьох мовах. Обтрунтовано, шуо ретельне вивчення продуктивних типів формування складних лексем допомагає виявити нові тендениії та закономірності у використанні наявних мовних засобів при формуванні новотворів, щз являють собою активно діюче джерело збагачення словникового складу англійської мови на сучасному етапі їі розвитку.
\end{abstract}

Ключові слова: функціонування, складне слово, композита, лінгвістичні дослідження, словоскладання, словотворення, семантична конденсація, інформативність, потенцііал, тендениії.

В статье обозначена роль композитологии - науки о сложном слове, которая развивается на фоне автономизации словообразования и обусловлена становлением словообразования как самостоятельной отрасли лингвистических исследований. Доказано, что возникновение композитов - это не специфический процесс, обусловленньй широким распространением в современном английском языке словосложения, а прежде всего одно из проявлений общего прочесса семантической конденсации лексики, характерное для многих языков. Обосновано, что тщательное изучение производительных типов формирования сложных лексем помогает выявить новые тенденции и закономерности в использовании имеютихся языковых средств при формировании новообразований, которые представляют собой активно действующий источник обогащения словарного состава английского языка на современном этапе его развития.
Ключевые слова: функиионирование, сложное слово, композита, лингвистические исследования, словосложение, словообразование, семантическая конденсаиия, информативность, потенциал, тенденции.

The present essay is focused on rather specific structural groups and models of lexical units not only in their present-day condition and historical development but also in their real functioning in language.

Intent attention to the sphere of their real functioning in speech, to the teaching about a compound word (composite) that is developing against the background of wordbuilding autonomization is conditioned by enormous interest existing in modern linguistics to compositology, by the position of wordbuilding that is becoming an independent field of linguistic investigations, by the growing activity of English word composition in enrichment of the language word stock and by the lack of fundamental works in English word composition both in home and foreign linguistics.

The origin of composites comes forward not as a specific process, caused by broad circulation of word composition in the English language but as one of manifestations of the general process of semantic condensation of the vocabulary that is proceeding in many languages.

The growth of information theory of language units caused by the increase of the information potential of the society, by science and technical progress and intellectualization of modern life leads to cutting down the language surplus, to rationalization of language system.

Careful studies of productive types of composite formation helps reveal new tendencies and regularities to use the existing language means in the process of creation of new formations that present an active source towards enrichment of the English present-day word stock.

Key words: functioning, compound word, composite, linguistic investigations, word composition, word building, semantic condensation, information theory, potential, tendencies. 
Постановка проблеми. Основним масивом будь-якої мови, як відомо, є слова, зокрема і складні. Словотвір перетворився у самостійний розділ науки про мову і по праву зайняв своє місце поряд із лексикологією та граматикою. Як стверджує С. Кубрякова, словотвір $є$ тією ланкою в мовній системі, що відповідає за формування позначень елементів зовнішнього і внутрішнього досвіду людини [4, с. 4].

У лексико-семантичній системі англійської мови словотвір відіграє важливу роль, оскільки є одним із потужних джерел розвитку та поповнення словникового складу за рахунок наявного в його розпорядженні арсеналу функціонально-структурних одиниць. Даний спосіб словотворення (словоскладання) досяг значного розвитку саме на сучасному етапі, коли спостерігається бурхлива поява складних понять у різних сферах людського спілкування, соціально-економічному, науково-технічному і політичному житті. Крім того, в англійській мові процеси словотворення співвідносяться 3 тенденціями до накопичення багатослівних найменувань, номіналізації найменувань, а також із глобальною тенденцією мов до економії лексичного матеріалу, чим і викликаний так званий «композитний вибух», який проявляється в різних функціональних сферах та характеризується широким спектром комунікативно-стилістичних конотацій [1].

Одним із феноменів англійської мови $є$ наявність композитів. Це досить розповсюджені й одночасно найменш вивчені в сучасній англійській мові структурно-складні утворення, що відзначаються високим експресивно-стилістичним потенціалом і широким спектром комунікативно-стилістичних конотацій. Термін «композит» походить від латинського сотропеге - складати. Історія вивчення представлених мовних одиниць має багатовікову традицію: від критеріїв їх ідентифікації, граматичних характеристик, характерного складу, стилістичної й семантичної функціональності до дериваційних особливостей. Завдяки копіткій праці мовознавців сучасна лінгвістика має найбільш точне і адекватне мовному матеріалу визначення композита, що здатне сформувати остаточне розуміння зазначеного лінгвістичного явища. Так, Словник української мови поняття «композит» тлумачить як «слово, утворене способом поєднання основ, здебільшого за допомогою сполучного голосного» [8]. Зокрема, найбільшу кількість композитів в англійській мові зафіксовано серед іменників та прикметників.

Вивчення структури і семантики складних слів у сучасному англійському мовознавстві має важливе як теоретичне, так і практичне значення, адже від усебічного вивчення та опису національної своєрідності словоскладання залежить правильне вирішення ключових питань словотворення. Зважаючи на це, словоскладання в системі сучасної англійської мови - не тільки одне з основних джерел розвитку та поповнення словникового складу мови завдяки наявним у його арсеналі функціонально-структурним одиницям, а й ефективний спосіб удосконалення граматичної будови мови загалом.

Аналіз наукових досліджень і публікацій. Питаннями словотвору в англійській мові займалися як вітчизняні, так і зарубіжні мовознавці (Е. Кубрякова, О. Мєшков, Л. Омельченко, Л. Соловйова, Н. Фабб, В. Адамс, Л. Блумфілд, Л. Бауер та ін.), у дослідженнях яких значна увага приділяється не тільки проблемам розмежування складних слів і словосполучень, а й власне словотвірним особливостям складних слів.

Композитам як одному з основних джерел розвитку і збагачення словникового складу англійської мови присвячено дослідження Д. Дубравської. Критерії композитної номінації розглядає О. Селіванова, виокремлюючи денотативний, семантичний, критерій синтаксичної цілісності та критерій лексико-граматичної єдності слова. Порівнянню колоративної композити в англійській та українській мовах, зокрема дослідженню семантики колоративних композит у різносистемних мовах та визначенню типів внутрішньомовних зв'язків колоративної композити англійської мови, присвячено розвідки Х. Мелько.

Зважаючи на значний інтерес у сучасній лінгвістиці до композитології, становлення словотворення як самостійної галузі лінгвістичних досліджень, зростаючу активність словоскладання у поповненні словникового складу сучасної англійської мови, неабияке зацікавлення науковців окресленою нами тематикою, вважаємо за необхідне грунтовніше дослідити специфіку складних слів у сучасній англійській мові.

Мета статті полягає у виявленні структурно-семантичних і стилістичних особливостей синхронно-релевантних складних та складнопохідних лексем, що функціонують у системі композитології сучасної англійської мови.

Виклад основного матеріалу. Складному слову, як слушно зауважує О. Мєшков, відведено особливе місце в ієрархії лінгвістичних одиниць, а отже, воно заслуговує бути описаним в особливому циклі лінгвістичних дисциплін - в ученні про складне слово, назва якому - композитологія [5, с. 6].

Після афіксації словоскладання є найпродуктивнішим способом словотворення. За даними П. Царьова, серед загального обсягу англійських новоутворень похідні слова складають $37 \%$, тоді як складні - $63 \%$ [9, с. 28], що переконливо свідчить про особливе значення даного способу в системі продуктивного словотворення англійської мови.

Упродовж останніх років виділяються два основні спрямування в теорії композитології - семантико-орієнтоване (лексикологічне), в основу якого покладено складне слово як лексико-семантичний феномен, та синтактико-орієнтоване (синтактичне), що розглядає складне слово як продукт перетворення синтаксичних конструкцій.

Особливо яскраво і переконливо існування композитних одиниць як сталих словникових утворень проявляється через утворення 3 їх допомогою нових лексем: не лише загальновживаних, а й таких, що перебувають за межами мовного стандарту. Можна навести чимало прикладів дериватів даного типу, що мають загальновживаний характер: to moonshine (нелегально виробляти, продавати алкогольні напої), moonshiner (контрабандист, постачальник нелегального алкоголю), moonshining (самогоноваріння, нелегальний збут алкоголю); to pussyfoot (шахраювати, говорити натяками), pussyfooter (шахрай, людина, яка не висловлюється однозначно), pussyfooting (шахрайство, плутні, махінації); to dovetail (координувати, погоджувати), dovetailed (узгоджений, погоджений, належний), dovetailing (координування, погодження); apple-polisher (підлабузник, підлесник), apple-polishing (підлабузництво, підлещування). 
Структурно складні лексеми даного типу, з'являючись у побутово-розмовному мовленні, можуть слугувати ілюстрацією процесу нейтралізації просторічних елементів у літературній розмовній мові. Порівн.: grub-stake (амер., розм.) - давати гроші, матеріали, забезпечити золотошукача харчами і грошима в борг. They had grub-staked themselves from the proceeds of the raft and left Dawson for the headwaters of the Tanana (J. London).

Більшість англійських композитів виникають як жаргонізми чи сленгізми різної стилістичної та соціальної тональності. Лексикографічні посібники просто не встигають реєструвати процес «натуралізації» таких американізмів на британській основі. Серед жаргонних і сленгових лексем, зафіксованих словниками, варто виокремити такі: free-load - істи і пити за чийсь рахунок; gold-dig - вимагати гроші, подарунки; bullyrag - 1) дуже сварити (когось); 2) залякувати; 3) (сленг.) грубо, брутально жартувати, знущатися, глумитися (3 когось); rough-house (сленг.) - ухилятися, уникати від виконання неприємних обов'язків, лінуватися; glad-hand - радісно привітати; foot-slog (жарг.) - іти пішки, плентатися; brown-nose (жарг.) підлещуватися, вислужуватися, підлабузнюватися; knuckle-walk - рачкувати; double-cross (розм.) - обдурювати (когось), шахраювати.

Досить продуктивним способом в утворенні композитів-оказіоналізмів (nonce-words), що вживаються мовцем ad hoc (один раз у даній ситуаціi), є лексико-синтаксичний, що сприяє появі нових слів завдяки зрощенню в одне слово двох або більше одиниць. Такі оказіоналізми виникають як у ході живого спілкування, так і в писемному мовленні та виконують певну експресивно-стилістичну функцію. Наприклад: hen-peck (розм.) - тримати чоловіка під «каблуком»; cold-pig (розм.) - обливати холодною водою (щоб розбудити); hot-foot (розм.) - гнатися, нестись, летіти. Художні оказіоналізми - це продукт індивідуального авторського словотворення. Вони притаманні не лише художній прозі, а й літературно-критичним статтям, оглядам, нарисам, тобто творам, що мають певну емоційну спрямованість. Серед них можна виокремити такі: to double-hand - вести подвійну гру; to slow-handclap - «ліниво» аплодувати, виказуючи незадоволення або іронію; to waste-paper-basket «викрасити і викинути»; to night-club - розважатися в нічному клубі; to pigeon-hole - 1) розкладати папери по шухлядах; 2) (перен.) класти під сукно, відкладати у «довгий ящик»; to shortchange (амер.) - 1) обраховувати, недодавати; 2) обдурювати: We are shortchanging a whole generation of schoolchildren («Daily World», Sept., 25); to brown-bag - принести з собою їжу чи напої: This reporter chose to brown-bag it taking along some cheese and crackers (Canadian Tribune, June 10, 1980).

Уплив морфологічних властивостей частин мови, характери категоріального значення проявляються у семантичних особливостях композитів та в їхніх лексичних значеннях. Категоріальне, морфологічне, лексичне та словотворче значення композитів у цілому становлять семантичний комплекс, що відзначається неабиякою складністю, оскільки всі його одиниці взаємопов'язані між собою і взаємодіють одне з одним.

У сучасній англійській мові дієслова легко транспонуються зі складних іменників, фразеологічних зворотів або вільних словосполучень, отримуючи при цьому досить чітку цілісну оформленість: fish-hook (риболовецький гачок) - to fish-hook (упіймати на гачок); honey-moon (медовий місяць) - to honey-moon (святкувати медовий місяць, поїхати у весільну подорож); shuttlecock (волан для гри в бадмінтон, нерішуча людина) - to shuttlecock (вести нескінчені суперечки, бути жертвою пристрастей і обставин); buttonhole (бутоньєрка) - to buttonhole (затримувати (когось) задля стомливого і нудного висловлення почуттів); cold-shoulder (підкреслена байдужість, «прохолодне» ставлення) - to cold-shoulder (демонструвати «прохолодне» ставлення, ставитися 3 певною байдужістю, вороже); blackmail (шантаж, здирництво) - to blackmail (шантажувати, вимагати гроші); first-name (ім'я) - to first-name (звертатися фамільярнодо когось). Наприклад: «We've been emotionally blackmailed for a long, long time», - she added («Morning Star», 1989, Febr., 3); He first-named them, asked questions about their families (B. Appeal); He buttonholed people in the street and related the details of his child's miraculous progress (M. Mitchell).

В англійській оказіональній лексиці спостерігаються також випадки утворення структурно-складних дієслів шляхом лексикалізації синтагм, що виконують функцію звертання в конкретному мовленнєвому відрізку: "I've been dear Johned myself, if that's any consolation to you... You're not the only guy who ever got hit» (J. Ball). To dear John (фраз.) - лист, отриманий солдатом від дружини з проханням про розлучення. «My good woman. - Don't good woman me... (H. Wells). They my-loved and my-deared each other.

У процесі аналізу композитів допускається, що до семантичної структури слова (крім диференціальних сем, які розглядаються як приналежність денотативно-сигніфікативного компонента) можуть також входити конотативні семи оцінності, емоційності, експресивності. Конотативний аспект лексичного значення розглядається як єдність емоційного, експресивного та функціонально-стилістичного компонентів, що знаходяться у тісному зв'язку між собою. Емотивно-оцінний та соціально-мовленнєвий характер композитів $є$ основною причиною появи у сучасній англійській мові безлічі нових одиниць даного типу, що свідчить про їх комунікативну релевантність та функціонально-семантичний потенціал. Наприклад: catlick - мити як-небудь, абияк, ополіскувати; househunt (розм.) - шукати будинок, квартиру; piggy-bank - зробити підкоп під банк; eyeball - спостерігати, витріщатися; pump-handle - вітати, потискати руку; sweetheart - залицятися; tooth-comb ретельно оглядати, обдивлятися; tomfool - клеїти дурня; window-shop - розглядати вітрини, придивлятися до товарів; hot-foot (розм.) - гнатися, нестися, летіти; day-dream - мріяти,фантазувати.

Плодотворність поглибленого вивчення «перехідних» або «проміжних» нестійких та оказіональних новотворів, на думку Л. Омельченко, визначається необхідністю виявлення усієї різноманітності відношень між елементами мовної структури, що розкриває внутрішню динаміку мови у процесі іiі реального функціонування в різних комунікативних сферах. Багатоаспектність досліджуваного об'єкта потребує комплексного синхронно-діахронічного та системного підходу до його вивчення не тільки 
у структурно-семантичному, але й у функціонально-стилістичному плані, що забезпечує грунтовніший та адекватніший опис сучасного стану композитології англійської мови [6, с. 5].

У більш давніх дослідженнях із композитології, порівняно із сучасними, складні та складнопохідні лексеми розглядалися лише через призму їх структурних моделей незалежно від функцій цих утворень, тобто без їх призначення передавати інтелективну інформацію або мати спрямованість на створення максимального емоційно-оцінного ефекту, що вимагається умовами комунікації. Ціла низка морфологічно-складних конверсивів оточені ореолом образно-емоційної виразності та ідіоматичності, що нівелює змістову структуру слова і нерідко вимагає звернення до етимологічних та лексикографічних досліджень. Наприклад: to gooseberry - красти білизну 3 білизняної мотузки; to chestnut - повторювати старий анекдот; to blackjack (амер.) - бити палицею; to mickey-mouse (проф.) - синхронізувати музику з дійством на екрані; to snowboat (амер.) - пишатися, зазнаватися, діставати підлеглих, грати роль; to skyjack - викрадати літаки, займатися повітряним піратством.

Слід зазначити, що представлені вище структурно-складні одиниці також характеризують загальні тенденції еволюції мови та іiі лексичного складу подібно до того, як і безмежні потенційні можливості всієї аналітичної системи англійської мови. Крім того, вони існують упродовж багатьох століть, є комунікативно-релевантними, продуктивними і такими, що розвиваються, оскільки забезпечують можливість оформлення у мові нових понять, які виникають у зв'язку з безупинним розвитком людського суспільства, визначаючи подальше збагачення і вдосконалення лексичного складу сучасної англійської мови.

Функціональна диференціація складних і складнопохідних лексем проявляється не тільки у розподілі їх за функціонально-стилістичними пластами, що обслуговують різні сфери спілкування, а й у специфіці реалізації дериваційного потенціалу моделей у цих пластах. Вивчення усіх факторів, що мають вплив та обумовлюють процес утворення структурно-складного слова, дозволить не лише відповісти на питання щодо утворення лексичних новотворів, але й допоможе прогнозувати безпосередньо процес утворення нових слів завдяки використанню внутрішніх резервів перерозподілу і нової комбінаторики даного мовного матеріалу. Щоб досягти цієї мети, необхідні зусилля фахівців, які досліджують соціальні, психологічні та логічні проблеми у мовознавстві.

Історичний характер системи композитології забезпечує іiі спадкоємність, формування нових інтегративних якостей, збереження і розвиток елементів, які сприяють іiі оновленню, вдосконаленню, пристосуванню до нових потреб комунікації.

Висновки. Отже, поява в англійській мові композитів - один із проявів загального процесу семантичної конденсації лексики. 3 одного боку, композити функціонують як індивідуальні лексичні одиниці, що виражають зв'язки між компонентами, кожній 3 яких притаманні специфічні характеристики, а 3 іншого - кожному з них притаманні специфічні експресивно-стилістичні характеристики та комунікативно-стилістичні конотації. Виникнення композитів вмотивоване зручністю у використанні, стислістю, а також потребою в певних ситуаціях у більш експресивних, яскравих метафоричних конструкціях.

При утворенні складного слова із двох інших значення композита загалом багатше, ніж значення його окремих компонентів, позаяк значення першого компонента не вичерпує видових властивостей. Другий компонент може бути вжитий не лише в прямому, а й у переносному значенні. Компонентами композитів часто є лексеми, які значно посилюють їхню стилістичну значущість, образність та емотивність, що напряму залежить від семантичного наповнення їх моделей.

Подальші дослідження плануємо присвятити вивченню загальних принципів моделювання словоскладання сучасної англійської мови, проблем синтаксичної функції англійського словоскладання та їхньому розгляду в межах конотативної лінгвістики та в культурологічному ракурсі.

\section{СПИСОК ВИКОРИСТАНОЇ ЛІТЕРАТУРИ}

1. Доміненко Н. В., Кіслухіна М. В. Функціональне словоскладання в термінології сучасної англійської мови. Litera. 2019. № 5. C. 93-104. URL: https:// nbpublish.com/library_read_article.php?id=30969 (дата звернення: 20.05.2020).

2. Иванов А. Н. Пополнение словарного состава современного английского языка (опыт лексикологического и социолексикологического описания) : дис. ... канд. филол. наук. Москва : Наука, 1971. 312 с.

3. Клименко Н. Ф. Композит. Українська мова. Енциклопедія / редкол. : Русанівський В. М., Тараненко О. О. (співголови), Зяблюк М. П. та ін. Київ : Вид-во «Українська енциклопедія» імені М. П. Бажана, 2000. С. 245.

4. Кубрякова Е. С. Теория номинации и словообразование. Изд 3-е. Москва : URSS : Либроком, $2012.83 \mathrm{c}$.

5. Мешков О. Д. Семантические аспекты словосложения английского языка. Москва : Наука, 1986. $208 \mathrm{c}$.

6. Омельченко Л. Ф. Английская композита: структура и семантика : автореф. дис. ... д-ра. филол. наук. Киев, 1989. 43 с.

7. Селіванова О. О. Актуальні напрями сучасної лінгвістики (аналітичний огляд). Київ : Фитосоциоцентр, 1999. 148 с.

8. Словник української мови онлайн. URL: https:// sum20ua.com/?page=1367\&wordid=177423 (дата звернення: 12.06.2020).

9. Царев П. В. Продуктивное именное словообразование в современном английском языке. Москва : Изд-во МГУ, 1984. 225 с.

10. Шадрин В. И. Семантико-синтаксическое исследование сложных существительных в современном английском языке : автореф. дис. ... канд. филол. наук. Москва : Наука, 1977. 15 с.

11. Шевченко Г. Н. Продуктивность модели морфологические сложных слов с первым субстантивным элементом типа to baby-sit в современном английском языке : автореф. дис. ... канд. филол. наук. Киев, 1976. 21 c.

Дата надходження до редакиіi:: 21.07.2020 p. 